\title{
Textiles préhistoriques : synthèse et approches nouvelles
}

Dominique Cardon

\section{(2) OpenEdition \\ 12 Journals}

Édition électronique

URL : https://journals.openedition.org/tc/702

DOI : $10.4000 /$ tc. 702

ISSN : 1952-420X

Éditeur

Éditions de l'EHESS

Édition imprimée

Date de publication : 1 novembre 1992

ISSN : 0248-6016

Référence électronique

Dominique Cardon, "Textiles préhistoriques : synthèse et approches nouvelles », Techniques \& Culture [En ligne], 17-18| 1992, mis en ligne le 10 janvier 2006, consulté le 29 septembre 2022. URL : http:// journals.openedition.org/tc/702 ; DOI : https://doi.org/10.4000/tc.702

Ce document a été généré automatiquement le 29 septembre 2022.

Tous droits réservés 


\section{Textiles préhistoriques : synthèse et approches nouvelles}

Dominique Cardon 